\title{
3 Death and dying vs. COVID-19
}

\section{A hermeneutic approach toward understanding the social process}

\author{
Maria Łuszczyńska
}

Being unable to cure

death, wretchedness and ignorance,

men have decided, in order to be happy, not to think about such things.

Blaise Pascal

In this chapter, a hermeneutic analysis of the phenomenon of death will be undertaken. Death is a universal experience of the human condition; however, in the era of the COVID-19 pandemic, the disease can reveal new social processes that may transform society's attitude to death. These reflections aim to answer how the COVID-19 pandemic may affect people's attitude to death and if it encourages or distances them from searching for answers to existential questions. This the first modest attempt to present social phenomena in the perspective of the hermeneutics of death with regards to possible changes in social awareness and identity in the 'COVID-19 era'.

\section{Introduction}

According to anthropologists, awareness of one's impending death is one of the elements that distinguishes humans from animals (Vuillemin 1993). As a universal, future, and inevitable event that affects every member of society, death has always aroused the great interest of both individuals and entire communities. The SARS-CoV-2 pandemic has intensified the social processes of experiencing dying and death, although it still remains unknown to what extent.

COVID-19 spread around the world throughout 2019 and 2020. Although it was disregarded and treated as a local threat at first, within a couple of months, it spread around the world. It began its crusade in the Chinese city of Wuhan and then developed into several dozen mutations typical for various regions of the world at a rather dynamic pace ${ }^{1}$ (https://www.bloomberg.com/news/articles/2020-04-22/iceland-is-the- 
perfect-country-for-studying-covid-19). And it is still attacking. According to statistics published on Bloomberg.com as of 30 April, since January $2020,151,592,370$ people worldwide had been infected with the coronavirus. This means that based on official data, as of 1 May 2021, 2\% of the world's population had been infected with SARS-CoV-2 (https://www.bloomberg. com/graphics/2020-coronavirus-cases-world-map/). These figures certainly do not reflect the pandemic's actual state as they fail to take into account people who self-medicate or have asymptomatic COVID infections. In addition, there may be limitations in the number of cases resulting from disproportionate testing. In many countries, particularly those less industrialized and less developed, national statistics do not reflect the true scale of the phenomenon. Estimates suggest that when considering these factors, the actual number of infections worldwide is ten times higher, i.e., one fifth of the world's population has been infected with Sars-CoV-2 within the last year ${ }^{2}$ (https://covid-model.net/).

This proves the speed at which the virus has spread and the official number of deaths caused by SARS-CoV-2 indicate its danger. As of 1 May 2021, the number of people worldwide whose death is believed to be caused by COVID-19 amounted to 3,184,017 (https://www.bloomberg.com/ graphics/2020-coronavirus-cases-world-map/). These numbers are updated on an ongoing basis. Given that doctors determine the cause of death, it can be assumed that these figures may also be underestimated and overestimated. The difference in numbers is due primarily to discussions about whether COVID-19 itself is a direct cause of death or contributes to the patient's general health condition and occurrence of underlying illnesses. Medical specialists claim that the actual number of deaths caused by the coronavirus pandemic will be significantly higher in coming years due to the unknown magnitude of delayed negative impact on human health.

Due to its magnitude, the COVID-19 pandemic has had an exceptionally significant impact on social life. Among the solutions introduced by certain societies, there have been complete or partial restrictions in social and professional interaction, closures of public space, including educational, cultural, recreational, sports and gastronomical facilities. The pandemic has also affected professional activity and has placed significant limitations on health care services, which consequently that has been dominated by a systemic reaction to SARS-CoV-2 infections. From the state's perspective, these restrictions were based on fear of an economic crisis resulting from extreme loss of human life due to the pandemic. On the other hand, citizens complied with these restrictions out of fear of death. On the one hand, this fear led to aggressive attitudes towards people who had come into contact with the virus (e.g., health care providers or sanitary service officials). On the other hand, it made people realize on a mass scale the common need to support members of a given society whose access to goods and services has been cut off. Fear of death brought to life both the best and worst in people, depending on their ability to control it. 


\section{The social understanding of death: from acceptance to tabooization}

The dying process, brought to an end by death itself, is the most universal of all human experiences. It is also often said that death is the fairest experience that treats everyone equally - regardless of social status, wealth and other factors determining our social position. The process of death occurs in parallel to the process of our lives. Death is a reliable life companion. Over the ages, many philosophers and philosophical thinkers have created multiple theories on human death. Practically every philosopher who has addressed ontological and epistemological issues has offered their own interpretation of human life and dying ${ }^{3}$

(http://www.jednota.pl/archiwum/o-smierci/303-jednostka-wobecmierci).

Personal awareness of this common fact of human existence may elicit various reactions. On the one hand, people may be conscious of their mortality and make decisions regarding different attitudes - namely, feelings, behaviours and thoughts. On the other hand, they can gradually repress knowledge of their inevitable mortality. Death is then experienced indirectlyas an event occurring in other people's lives in various degrees of social proximity. It may also be denied entirely and thus ignored until the final years or months of one's life. Death then remains unexperienced, marginalized, isolated and hidden. In this case, it could be said that the dying process, experienced by all, becomes the most profoundly repressed truth concerning humanity. While reflecting on the social dimension of dying and death, the following elements constructing this dimension can be distinguished:

- the process of shaping social awareness about death, including thanatological education;

- relationships with those dying - social rituals, the social status of dying individuals and attitudes towards these people;

- social rituals associated with fatal illnesses, death and funerals;

- issues relating to procedures and customs of dealing with corpses;

- funeral ceremonies - rituals, cemeteries;

- the commercialization of funeral services;

- the mourning process - people's social situation after losing a loved one;

- society's cult of the dead, notably the departed who enjoy above-average social attraction;

- legacies, insurance, inheritance, wills, and benefits/losses caused by death, not only financially but also in terms of intergenerational transfer.

Over the years, various societies and cultures have created social norms to deal with death in relation to the elements mentioned above.

In particular periods of history, attempts were made to become accustomed to this event by means of developing a set of behaviors and rituals that were to be applied within the communal experience of death. Initially, 
death and all associated ceremonies changed the community's time and space in an essential way. Moreover, it impacted the family and the entire village, local environment, urban residential areas, and larger spaces of social perception. At the dawn of social history, people died in public, and the entire community reacted to their death. In primitive cultures, anyone was allowed to enter the dying person's residence, even if they were unknown to the family. For example, in early Poland, the funeral ceremony consisted in displaying the corpse in the house of the departed (usually for three days) accompanied by all-night mourning and prayer. On the day of the funeral itself, people gathered to take the deceased's body from the home, hitting the threshold three times as a sign of his/her bidding farewell to that place. Afterwards, the body was led to the grave in a funeral procession, followed by a mourning feast (the so-called funeral meal). After these ceremonies had concluded, the mourning process began that customarily lasted a year; however, there were cases in which the mourning period could have lasted for years or until the death of the person in mourning.

In the Middle Ages, death was a universal human experience; awareness of it accompanied people's daily thoughts and actions. The remembrance of death contributed to the emergence of axiological systems upon which the social order was built. Temporal concerns were considered in the context of the 'vanity of life'. The medieval saying memento mori (remember that you have to die) constantly served as a reminder that everyone was mortal and simultaneously functioned as the moral regulator of human behaviour.

Death is also a common human experience in the face of epidemics decimating the population, high infant mortality, frequent wars, all forms of battle, and public executions. Almost every adult has had to confront death and the sight of dead bodies. Moreover, both adults and children die. Cemeteries were located in the centre of the settlement as a reminder of the inevitability of death.

The social understanding of dying and passing was deeply rooted in faith, which gave birth to a specific belief: dying was considered a process of passing, and death was the next stage of life and not its conclusion. This faith enabled people to better cope with dying. Furthermore, death was also treated as an indisputable decision made by God, which evoked fear or even extreme terror, but it was met with passive acceptance rather than resistance. After all, God gives life and decides when it comes to an end. Although there were many emotional reactions to the death of loved ones, including despair and sadness, death was always treated naturally and openly. Moreover, the person dying was generally aware of their condition. Death was preceded by various religious and family rituals that provided those still living with a specific pattern of behaviour in dealing with the situation. According to the Christian tradition, people who were dying had to reconcile themselves with God, say goodbye to their family, convey recommendations concerning the time after their death, and pass on a kind of will. As a rule, property was distributed. This openness to death made it a "tamed death" (Aries 1998). 
Changes in social attitudes towards death can be observed in the Enlightenment era. Developments in science and the progressive secularization of life began to diminish the impact of religious interpretations of death. Traditional rituals of passing also started to disappear; death began to be treated not as a vehicle transporting people from one existence to another but as a transition to nothingness. The role of the clergy, who assisted in carrying out the act of passing and offered interpretations of death to help people accept it, also diminished. The suffering encountered by the dying person, which earlier could be offered to God and treated redemption for sins, slowly ceased to fulfil this role and became an unnecessary and terrifying experience.

These changes triggered an increased fear of death and dying. However, death remained an element of everyday life. Children were not protected against knowledge of it, as is currently the case. At the same time, medical advancements gave the hope that death could be postponed.

An increasingly better understanding of anatomy and physiology and discoveries such as the microscope made it possible to diagnose and treat illnesses more and more effectively. Therefore, death was no longer inevitable when life-threatening situations arose. Such medical achievements offered hope that death can be conquered; however, at the same time, accepting and treating it in a natural way became more difficult.

During the Industrial Revolution, all of these trends intensified. The acceleration of medical advancements and the emergence of new medical technologies meant that once deemed incurable illnesses were commonly treated. Knowledge of aseptic procedures and the possibility of using ether in anaesthetics during surgery contributed to new successes. Personal hygiene and living conditions improved, and the average life expectancy increased. Mortality rates decreased, which was particularly visible in statistics on infant and child deaths.

At the same time, institutional medicine was developing: treatment, and therefore dying, occurred in hospitals increasingly more frequently. As a result, these events were distanced from natural human environments and moved from the sphere of direct family experience to medical facilities. 'Specialists' began to be engaged in the dying process, and those dying were surrounded by doctors and nurses and not their loved ones. People began to be seen as "patients" in categories of "health or illness" and as those dying in profound isolation, often without their families with them, in conditions of sterile isolation.

Distancing younger generations from death in the first half of the 20th century made the death of older people increasingly more noticeable. Visions of incurable illness emerged wreaking fear and havoc and were symbolized by screens and hospital isolation rooms separating/isolating the dying patients to hide their agony. Therefore, the hospital became a place of alienated, defenceless death with a lost individual character.

Patients do not want to die in a hospital; however, dying at home is not possible for many of them. Families and caregivers are not able to provide 
them with the appropriate conditions, around-the-clock care or, for various reasons, are unable or unwilling to do so.

The rise in the power of medicine also led to a re-evaluation of its purpose. Providing treatment and life support up to the final stages of life has become imperative for doctors, and a patient's death is considered a medical failure. Therefore, treatment is initiated even when everything suggests that nothing can be done to save a patient's life. Spectacular healings in hopeless cases indeed occur, which sustain faith in the efficacy of fighting death until the very end. However, such situations are rare, and in the majority of cases, they lead to additional suffering for the person dying, particularly when intensive and aggressive treatments are applied.

Moreover, new ethical problems arise. Such issues include the definition of death and determining the moment it occurs, moral conflicts associated with prolonging life or hastening death, medical experiments and organ transplants from deceased donors, and even questions related to speaking with the dying about their impending death.

Death ceased to be a direct social experience and began to be subject to tabooization - it was forced out of the common social experience. Tabooization intensified more or less in the period of the First and Second World Wars due to vast number of deaths and defensive desensitization to it. In the mid-20th century, death ceased to be a public ceremony and was 'pushed into the realm of deep privacy'. 'Discrete' funerals attended by the deceased's closest family and friends were much more common. The family asked that condolences not be offered, signs of mourning disappeared, and expressing pain and despair after losing loved ones became unnatural and unfashionable. Several factors testify to tabooization:

- reluctance or even avoidance of any contact mediated by the senses, e.g., something or someone associated with dying and death. This tendency can be vividly observed in situations in which someone requires reanimation in a public setting. The reaction of witnesses clearly shows that what occurs in such situations can be described as the depersonalization of death;

- restraint in showing emotions, or suppressing and not flaunting any signs of mourning, the dominance of the denial of death rather than coming to terms with it through experience, as well as efforts aimed at returning to 'normal' as quickly as possible, i.e., life prior to someone's death. In the contemporary experience of mourning, there is not much space for grieving, mourning and resentment;

- the absence of communication (from direct to mediated forms, broadly understood cultural texts and media images), the lack of conversations about issues relating to death and silence in this regard that leads to the belittlement of death and dying. This fact may be associated with reluctance to cause oneself pain, and in a certain way, is related to and directly engaged in the dying process or the death of a close loved one. 
Death and dying are awkward topics. There are euphemisms used that aptly avoid the bluntness of death, i.e., "someone passed away." People began to hide the dying process from the dying themselves, and reluctance to be in their presence has increased. We avoid visiting them, even if they are our close friends. Often, news of an incurable illness results in the patient's social isolation precisely because of the inability to address this complicated topic. New terms emerge, including the death crisis (Bauman 1998), code of silence (Kastenbaum 1973), deconstruction of mortality (Bauman 1998; Berger 1997), denial of death (Gorer 1955), sequestration of death (Mellor 1993), dying of death (Walter 1994), and wish-dream (Gorer 1955). British sociologist and anthropologist Geoffrey Gorer, considered the pioneer of the sociology of death, was the first to employ the term 'tabooization'. Gorer's text is already a classic. However, the thesis taken from his pioneering speech, in many respects, is still today one of the critical issues of debate in thanatology and the sociology of death. Gorer assumed that specific topics and areas of human experience are treated as being inherently scandalous or offensive. Therefore, they are not to be discussed or mentioned openly; and experiencing them is done in secret and associated with feelings of guilt or inferiority. According to Gorer, death as a natural process has become gradually unspeakable, and therefore placed in the sphere of taboo as was previously the case with sexuality. While the taboo of sexuality gave way to the spread of perverted sexuality, taboos on dying have resulted in the eruption of the pornography of death today.

Consequently, natural death is increasingly disguised by prudishness, while violent and unrealistic deaths play a more predominant role in the mass media and pop culture. Death is removed from the horizon of awareness, the sphere of human and emotional experiences, thus allowing the so-called "pornography of death", which means the fashion for ubiquitous and blatant death connected with aggression, slaughter, blood, massacre and violence. In effect, death is trivialized, ridiculed, exaggerated and even treated as amusement. This distorted image of death appears in news broadcasts, pop culture, art, films and advertisements. It could be said that they depict death in the third person - it affects him/her or them. It rarely affects the second person - you (singular), you (plural), and never as me/us. In this manner, the primal human fear of one's own death is neutralized, displacing traditional customs associated with mourning, which points out the extent that contemporary people are not able to cope with fundamental existential problems.

In conclusion, the crisis of death described as 'inverted death' (Aries 1998) is based on pushing death beyond the boundaries of social awareness and that of the individual, a process that is only deepening in the post-modern era. This process is caused by the following factors:

- the medicalization of death - removing death from social awareness due to medical advancements;

- the secularization of life - reducing the significance of death and religious practises related to death; 
- industrialization and urbanization - concentrating social awareness on progress, changes in social structure and environment, and work culture;

- technological progress - associated with medicine and treatment procedures;

- demographic changes - prolonging life, improving its quality, decreasing the number of deaths in children;

- transformations in the hierarchy of social values - in the emerging industrial relations, healthy, non-disabled and productive individuals enjoy greater recognition than the older adults who were once appreciated for their life experience;

- changes in family structures - 'branched', multi-generational families have been replaced by nuclear families characteristic for urban life. Family ties have weakened, and younger generations have started to lose their ties with older family members, who were most often ill and dying.

These tendencies lead to the progressive marginalization of older people and turn society's attention from their problems, illnesses, disabilities and dying process. Consequently, the negation and removal of death from social awareness are deepening, and this phenomenon has dominated people's attitudes towards death since the mid-20th century.

Early cultures, more immune to death, created the model of 'tamed death'. People died at home, surrounded by their close family, reconciled with this fact (Aries 1998; Vovelle 2002, 2008). Today, significantly more people would rather die quickly, painlessly, under anaesthesia, or when asleep. For this reason, the topic of death is ignored, silenced and uncomfortable. Medical advancements have abolished the clear line between life and death and have led to the institutionalization of death. This has also impacted the way death is perceived.

\section{The hermeneutics of dying and death}

The hermeneutics of death, understood as the capability of experiencing and describing the end of one's life, cannot be experienced since the possibility of reflecting on the final moment of one's life ends with death itself. The hermeneutics of death can only be reconstructed indirectly by understanding the death of others, most often that of close friends and family. It is associated with a voluntary and conscious decision to come into contact and in relation with a dying person, which may be difficult due to fear of death.

Since death is inconceivable to human reason, thanatologists have been developing a more accessible version - the hermeneutics of dying, which is emerging as a very 'human', and at the same time, humble and curious reaction to the phenomenon of death. Here, hermeneutic thought returns to its sources. In addition to focusing on understanding, it attempts to determine the conditions for understanding it, and - as a manifestation of the human 
factor - to tear away even a fraction of that which can be grasped by reason, that which cannot or wills not to be understood - i.e., the mystery of death.

That which can be grasped in the hermeneutic perspective is not the state of death but rather the dying process itself. Thus, what is to be understood is never fully comprehended but is constantly being discovered. On the one hand, the subject of hermeneutics is awareness of the inevitability of death as an element of life, a certainty of existence, but also certain paradoxical, and by definition, imperfect anti-experiences of death associated with a lack of experience and knowledge that can only be anticipated as an impression, feeling or imagination. Thus, this inability to experience 'the inability to experience' is absolute philosophically but not existentially.

The hermeneutics of dying concerns situations in which the reality between life and death meet as closely as possible. It is only in this space 'in-between', where life has almost come to an end and death has almost occurred, that it is possible to find out about something that resembles death as closely as possible. The hermeneutics of dying possesses yet another feature that the hermeneutics of death does not - namely, the language by which it is possible to describe what can be understood (Gadamer 2011).

In the context of dying, language is expressed in the message of the deceased's final will, his/her instructions and desire concerning the future, or as a farewell. These messages are connected with the final moments of life and expressed in the presence of witnesses. Today, wills are drawn up at an earlier time, are anticipatory in nature and may be subject to modification. Although expressed in the broader context of life, the words of the will momentarily bring the person expressing their last will into contact with the awareness of their own dying process. One could speak of the anticipatory dimension of the hermeneutics of dying, which concerns me as 'myself' and in the participatory dimension, i.e., concerning my participation in the dying 'you'. The latter is the only possible situation in which an informed hermeneutic description can be made. Furthermore, "my death" is beyond the scope of leaving an inheritance; however, 'your death' is the only area in which dying and death can appear and be constantly described.

Among the authors who have contributed to the hermeneutics of death, predominant hermeneutic thinker Hans-Georg Gadamer should be mentioned. While reflecting on the experience of death, he looked at the accomplishments of technology and pharmacology made for the benefit of not only palliative care but also for supporting human life (or rather the functions of life) beyond its "natural" measure, with slight horror. Thus, death is not only isolated from the public sphere, but it is also "alienated". Gadamer claims that "modern chemistry, equipped with anaesthetics, expropriates the person suffering. (...) At the same time, it also excludes those who have experienced, either by passive or active participation, this event" (Gadamer 2011: 80-81). Therefore, it follows that both death and dying are worth (consciously) experiencing and are an integral and key element of human, and therefore - intelligent existence in the world. 
Thinkers are surprisingly unanimous in terms of the inability to emotionally or intellectually grasp one's own death. Ludwig Wittenstein claims that "death is not an experience of life. Death is not experienced" (Wittgenstein 2000: 81) and therefore, it would be better to remain silent about it. Sigmund Freud expressed a similar view in his text entitled Our attitude towards death when writing that "we cannot, indeed, imagine our own death; whenever we try to do so we find that we survive ourselves as spectators"4 (Freud 1918: 40-41). Martin Heidegger, in turn, wrote that "death, as a possibility, gives Dasein nothing to be 'actualized', nothing which Dasein, as actual, could itself be. It is the possibility of the impossibility of every way of comporting oneself towards..., every way of existing" (Heidegger 1994: 368). Zygmunt Bauman claims that "the only thing that thought cannot grasp is its own non-existence" (Bauman 1998: 21). Similarly, the "father of thanatology", Luis-Vincent Thomas, wrote that "as long as we are alive, death exists in the images it suggests, and in the language that we use to describe it" (Thomas 2002: 11). Attempts to describe the experience of dying and death are possible by understanding it in categories of the mutual relation of I and Thou. Thinkers such as Martin Buber, Emanual Lévinas, and Józef Tischner wrote about the significance of this relation. The mediation of experience in someone else's dying process causes that I better describe the dying process of Thou than my own, because My process is My drama, from which I distance myself or despair over. The dying of Thou, regardless of how painful it is for me because of the relationship of I and Thou, allows for greater awareness of this process with engagement, but without avoiding it. It could be said that participation in the dying of Thou is the foreground to my own death. Some authors have supplemented this relation with the aspect of the love shown to the dying person (Buber 1992; Jankélévitch 1993; Levinas 2012; Tischner 2005, 2006; Ziemiński 2007). By this love, one experiences his/her own death despite the impassible ontological barrier between Thou and I. To the extent that the love-based subjective I-Thou relationship brings to life the new being 'We', 'Us' - to that same extent, the death of Thou turns out to be, to some degree, the death of I. Although the I does not die physically, temporarily, it dies as the object of the I-Thou relationship. The death of Thou destroys the I inasmuch as it was engaged in its relationship with Thou, most often by virtue of love (Ziemiński 2007).

The dying process is rooted in time. From the perspective of $\mathrm{I}$, it is permanently embedded in the future. However, if the I experience the death of Thou, understanding this process may refer to the past, present, and to the future (Jankélévitch 1993).

The knowledge that we obtain thanks to the death of Thou, is a profound, personal existential experience and is something radically new in relation to everything that we had previously known. Before the I was affected by the death of Thou, the I saw was only the objective law of nature in human dying, to which we are all subject. However, after experiencing the death of Thou, an understanding emerges that transcends the ordinary description 
of nature and now engages not only in academic objectivity but also in subjective emotional, intellectual, and often spiritual engagement.

Understanding, language, time and the I-Thou relationship are the elements of the hermeneutics of dying that may be employed when analyzing the impact COVID-19 has on the awareness of dying and social attitudes towards death. Later in the text, they will be used for preliminary analyses of the social reality that has constantly been evolving since the global pandemic outbreak. The main subject of the analyses is that what is currently taking place in the social understanding of death, whose shadow has been the broadest context for all the behaviours, reflections, images and experiences that have organized social life in the COVID-19 era.

\section{The fear of death as a social force that builds the identity of (im)mortality}

The peculiar marginalization of death has contributed to the social distortion of the image of death, which has changed from so-called "tamed death" into "death gone wild", driven out of everyday life. The extent to which death is feared indicates the scale of taboo, but the main problem is found in using such concepts as denial or the two-dimensional fear: conscious unconscious.

In attempts to understand how COVID-19 has impacted attitudes towards dying and death, it is crucial to look at the fear that death invokes and the attitudes people may have in reaction. Makselon distinguishes three main components of the attitude towards death: (1) thinking about death; (2) fear of death; and (3) defence mechanisms (Makselon 1983). In turn, A. Ostrowska believes that fear is the most crucial dimension of the attitude towards death [28]. Judging by the amount of academic work devoted to the particular dimensions of the attitudes towards death, this is currently the dominant opinion (Cicirelli 1998; Feifel \& Branscomb 1973; Gesser et al. 1998; Kaatenbaum 1973; Neimeyer 1994; Tomer \& Eliason 1996; Yalom 2008).

In Gebert's opinion, death can be feared only when it is imagined, and since it is a particular negation of existence, one must first be aware of its existence. From this perspective, the fear of death is one of the most fundamental elements of one's self-awareness; to a great extent, it regulates human behaviour and is inseparably associated with the awareness of one's own existence (Gebert: http://www.jednota.pl/archiwum/o-smierci/303jednostka-wobec-mierci). The fear of death can be viewed in various ways as the fear of one's own death or the death of loved ones, fear of the moment of death or the dying process, fear of what happens to the body after death, and fear of the way we think about death and negative thinking about it. However, fear always engages one's personality, and everyone experiences it uniquely. Ochsmann (Jastrzębski: http://www.psychologia.net.pl/artykul. php?level=209) distinguished six types of the fear of death: 
- fear of encountering death that manifests itself in fear of direct contact with a dying or deceased person;

- fear of mortality expressed as the fear that one's plans and intentions will be brought to nought by death and fear of confronting the sufferings experienced by close friends or relatives;

- fear of the end of one's life expressed in refusal to accept death understood as the definitive end of existence;

- fear of physical destruction linked with an intense fear of what will happen with the body after death;

- fear of life after death triggered by the terrifying perspective of the uncertainty of what will take place after death;

- fear of the dying process and the suffering that accompanies death.

The fear of one's own death refers to the feeling of the irreversible passing of time in human life and development and the end of one's own existence, over which we have no influence. This fear may concern various aspects (Makselon 1983):

- dying, i.e., approaching death;

- destruction of the body after death;

- surviving relatives;

- the unknown, and the unknown moral judgement of God

- apparent death, at times the result of stories of burying people still alive;

- premature death, when one is still fully active;

- the appearance of the body after death;

- a specific type of death;

- social - psychological death - understood as the absence of interpersonal relations

Many factors impact one's attitude towards death. Such factors include an individual's propensity to fear, life-threatening situations, experiencing someone else's death, concern for life and its prolongation, religious and cultural factors that shape various interpretations of death and provide it with meaning. Attitudes towards death change throughout one's life, but they always constitute the social context in which death occurs. Social convictions about death are reflected in customary practises, in legally binding legislation and institutional statuses concerning death that regulate the conditions of dying and significantly determine the interaction between the dying and their environment.

The fact of dying is closely related to attitudes towards death. According to E. Kübler-Ross, the dying process includes stages that differ in terms of the essence and intensity of the dying process and one's acceptance of the inevitability of death. She conducted several hundred conversations with the terminally ill, which in turn allowed her to distinguish five reactions to death, also known as stages of dying: denial and isolation, anger, bargaining, 
depression, and acceptance (Kübler-Ross 1979, 2005). In another typology developed by Szaniawski, the following attitudes are distinguished depending on our personality (Szaniawski 1998):

- ambivalent - is aware that death is a value but constitutes the greatest uncertainty, a sad necessity, the end of hope and a tragedy. One fears death but also attempts to think about it;

- calm - accepts death; according to such people, death is not a tragedy, but a mystery, the path to rebirth and cleansing. Thinking about death motivates them to make changes in their life;

- religious - understands death in the context of faith but does not always live according to it. Such people often think about their own death and that of their close family and friends, but this does not prevent them from having an optimistic outlook on life. Death is understood as unity with the Absolute;

- evasive - they do not think of their own death, do not consider it to be the most important issue and do not consider it a tragedy. Death does not frighten such people; however, they often think of the death of close family and friends;

- terrified - death is the main problem in life and the greatest uncertainty. Such people fear death and often think about it; however, their reflection does not help them live a better life.

According Kaczmarek, the contemporary attitude to death has at least three aspects that impact people's social activity with regards the dying process: (i) adopting an indifferent attitude, treating death as obliteration and negative; (ii) rooting it in a theological horizon that merges dying with the perspective of eternity, the thought of which should guide one's earthly life; and (iii), the 'taming death' effect - hospice movements that are not always related to a particular religious discourse, however, they restore death its social acceptance and reject the indecency of suffering and illness (Kaczmarek 2009).

Summing up these reflections, contemporary social reality in relation to death is characterized by the following phenomena which coincide with:

- the tabooization of death - the avoidance of speaking and thinking about death, removing it and dying from daily life; for the majority of people, dying takes place in hospitals, alone, surrounded by medical specialists; a commercial approach to funeral rites, the family does not participate in preparing the deceased for the funeral;

- pornography of death - death becomes the subject of spectacle and fascination. It is shown, e.g., in sudden, violent death scenes in films, computer games, trivializing and ridiculing death, etc.

- the medialization of death - together with the development of new technologies, new forms of commemorating and mourning the deceased 
have emerged - and its promoter and driving force has been the Internet. Increasing more often, people watch funeral ceremonies on the Internet. Virtual cemeteries, monuments and virtual candles, similar to traditional candles or lamps, or are marked with special graphic signs reflecting grave candles, are increasingly more common. In the scope of this phenomenon, the cult of the dead or famous people - religious figures, people of the arts and culture or celebrities - has emerged, taking on a global character, thanks to the community of mourners worldwide. Examples include the global mourning of the deaths of Princess Diana, John Paul II or Michael Jackson.

- The retabooization of death - the dynamic development of academic thanatological reflection and the development of the hospice movement, palliative care, organized social campaigns for a good and dignified death. An element of retabooization is restoring to funeral rituals and the mourning process a form that assists in overcoming the pain experienced after losing a loved one but simultaneously helps in coming to terms with the awareness of one's own passing.

Admittedly, in response to the process of tabooization, social activities have emerged that are aimed at re-taming death and giving it a humanistic character, including hospice movements, social campaigns (e.g., the 'Dying Humanely'), but changes in thinking about dying occur very slowly. In what way does COVID-19 contribute to accelerating changes in the area of understanding death?

\section{COVID-19 and the social (mis)understanding of death}

If we accept Gennys Howarth's argument that the fundamental problem for sociology is the question of how societies can endure in the face of mortality, the concept of death as a taboo can definitely be treated as an attempt to explain this phenomenon in relation to modern societies (Howarth 2008). However, what is COVID-19s role in the development of the social understanding of death? Does it contribute to even greater tabooization, or does it perhaps introduce a new aspect to the process of de-tabooization due to its global and long-lasting nature? COVID-19 appeared at a time when the social understanding of death could have been viewed as being subject to tabooization than to taming. Social actors awaited a medicine for immortality, medical "specialists" (doctors, nurses) made use of cutting-edge technology in treating people and prolonging their lives. Moreover, the pharmaceutical industry has made huge profits on selling medication and supplements to keep people in good health or extend their lives without death. The global economy has generated profits, and sales markets have produced increasingly more needs to keep the economic wheel spinning. The outbreak of the pandemic was a shock world-wide that revealed the unpreparedness of medical, social, academic and political environments in coping with this 
unknown type of threat. Reactions to the spread of the virus varied, often extreme, resulting in conspiracy theories and explaining the situation with great depopulation narratives.

For the first time in history, a pandemic spread throughout the social life of inhabitants of the Earth to such a great extent. Its emergence revealed people's emotions on a massive scale. The first emotion that guided political, economic and social actions was the fear of death. Although it was not mentioned for months, it was the driving force behind the solutions adopted by specific states. These drastic measures included closing borders, restricting movement, economic lockdown, prohibiting the sale of goods and services unrelated to basic food and medical needs, closing educational institutions (preschools, schools, universities) and socially isolating people infected or suspected of being infected. It can be noted that during the first stage of the pandemic, aside from fear for one's life, feelings of uncertainty, senselessness, crisis, fear of the unknown and the future dominated. For some, this was associated with martial law, only the nature of the opponent was unknown. People employed five basic strategies for social existence:

- disregard - distancing oneself from the situation, functioning as if nothing had happened, not listening to the news, living one's life and avoiding obstacles that appeared in the social environment as a result of COVID-19; extreme forms of disregard may include misunderstanding what is happening and lack of interest in the situation;

- revolt - based on breaking restrictions, searching for conspiracy theories to explain events, refusal to comply with recommended precautions (great discussion on wearing masks), using arguments related to civil liberties, freedom of choice, etc.

- resignation - based on the gradual loss of hope, deteriorating mental health condition, the extreme form of which is panic, nervous breakdown or auto-aggressive behaviours.

- acceptance - coming to terms with uncertainty and change and creating constructive personal strategies adapting to further life; characterized by calmness, hope for the future, and expecting the situation to improve.

- co-operation - based on keeping up-to-date about the pandemic and undertaking action to support those in need and those who have experienced difficulties in coping with the pandemic situation. In terms of co-operation, people have engaged themselves in social campaigns by sewing masks, going shopping for the older adults, caring for the ill, etc.

The activities mentioned above may intertwine or transform from one to the other. This list of activities is also the effect of social observations and requires further social research conducted after a certain period and with a particular distance to investigate the dynamics of such changes. The driving force behind these attitudes was undoubtedly the fear of death - whether conscious or not - driven by the media or political messages. Therefore, the 
COVID-19 situation has been, in principle, thanatological in nature. Various social actors have been involved in the situation that has arisen as a result of COVID-19. Among other examples of the COVID situation referring to the hermeneutics of dying, various situations that build the thanatological character of social experience can be mentioned:

- the ill - "patient" at risk of death

- specialists providing care for those infected with COVID-19 (doctors, nurses, patient services)

- the family of "patients" and later the deceased

- the older adults, who as an age group were more at risk of contracting COVID-19 other groups

- members of a given local community that are potential participants in funerals

Each of these situations is extremely rich in terms of research into the impact on individual and social awareness of dying. These situations reveal the social aspect of attitudes (behaviours, emotions and beliefs) towards the dying process and someone else's death. By examining each of them, it is possible to notice new, unknown or more intensified relations, behaviours and experiences related to death. When analysing them in detail, it must be emphasized that the social role of patients is characterized by being isolated from family and staying in a hospital environment where medical professionals surround them. In addition, due to the sanitary rigour, patients have to deal with unusually dressed personnel with whom sensual contact (by means of sight, sound and touch) is extremely limited. The sight of people dressed in special suits, masks and visors may deepen a dying person's feeling of being in an unreal, absurd and uncertain situation dominated by suffering, fear, loneliness and despair. The accounts given by volunteers who support dying patients bear witness to the enormity of the confusion experienced by those in the dying process. This is undoubtedly an interesting topic for further research since the description of experiencing such dying is certainly more intense and characterized in a way so far unknown.

In turn, the attitudes of the medical personnel towards death are also exceptional and unparalleled in this regard. An element of their profession is the freedom to navigate oneself around the reality of regulations and processes, and having extensive expert knowledge. Their work is performed in hospitals where people fight for their lives, and death is treated as a failure. However, the COVID-19 pandemic has revealed the limitations of the health care system, not only in terms of equipment and capacity but also mental preparation. It has forced medical staff to exert inhumane physical, mental and emotional effort with the burden of the constant threat of their own death (as was the case in every country in which health care workers have died). They have witnessed the multitude of death among their patients and have been faced with the necessity of assessing who should receive their 
help and who has a greater chance of surviving in the context of limited access to medical equipment. The attitude of medical staff and attitudes towards medical staff on the part of those who witness their work and the local communities in which they have been perceived as a potential threat to the health of others - constitute a rich source of research material that could contribute to a better understanding of death as a social phenomenon.

Another group that has encountered the dying process, whether they like it or not, have been the families of 'patients', both those whose access to their loved ones in hospitals has been severed, and those who have lost their loved ones and have had to organize funeral ceremonies in sanitary regimes. Families have not had the possibility of accompanying their loved ones in the dying process, saying goodbye to them, accepting their wills or blessing for the journey ahead. They have also not been able to accompany their dying loved ones to ease their pain. They have been forced to organize modest funerals that could not be attended by all those who desired to pay respects to the deceased. Such families have been witnesses and participants in the 'funeral factory' - they have placed the corpse of their deceased in a family grave or mass cemeteries among hundreds of other graves. They have had feelings of complete alienation from the death of their close family members and friends that have left an unspeakable gap between the last time they met and their absence in family life. This situation has also arisen due to quarantine, and families have not been able to participate in a family member's funeral, thus making the gap even greater. Members of a given community in which someone has passed away have also had similar experiences, although to a lesser extent. Fear of infection, epidemic restrictions, and one's own powerlessness have caused the deceased to disappear from the social horizon in an almost invisible and unknown way, without saying goodbye. In this way, COVID-19 has transformed the character of social mourning. Compared to the pre-COVID era, even public figures (politicians, actors, singers, artists and celebrities) have died with reduced social response, mourning and sadness. It is as if the world has grown accustomed to death over time or has at least become immune to it.

An accurate assessment of the impact of COVID-19 on the development of thanatological knowledge will occur in the future, because distance is essential to reach comprehensive conclusions. It goes without saying that in the context of this historical moment, both negative and positive effects can be observed in terms of coping with death. The former may include the intensified isolation of those in the dying process - removed from family, the local environment, loved ones, and entrusted to health care services. As far as medical sector workers are concerned, their exceptional devotion and enormous effort to care for patients, even at the cost of their own health and lives, is evident. Coming into contact with death to such a great extent has renewed their fundamental motivation to practice their profession. It could be said that it has verified their professional vocation, albeit in connection with enormous effort. 
Undoubtedly, people have also started to reflect on the end of their lives and search for answers to existential questions to a greater extent than previously. However, attitudes of withdrawal and revolt have been noted, along with ones that feed on conspiracy theories. It could be said that the fear of death has intensified, which, on the one hand, could lead to dissent and social revolt, while on the other hand, to a bolder search for answers to questions that people are unwilling to ask. COVID-19 has also verified the quality of our social relations, revealed areas of longing and essential issues unrelated to consumption. It has become a strong incentive, occasion and pressure to reflect on one's own death. To a larger extent, it has confronted societies with the issue of death, and not necessarily from the point of view of dreamers in search of a medicine for immortality.

\section{For further discussion...}

For ages, the ceremonies of 'taming' death have been subject to numerous changes; however, the constant relationship between death and society has never been disturbed. The paradox of everyday life and death remains essentially an 'everyday' topic since it constantly accompanies life changes. However, at the same time, it is denied the most. Although death is a natural stage of human existence, it is simultaneously one of the most unwanted and avoided topics, and a taboo subject. Almost every discussion on this topic is reserved for philosophers, ethicists, theologians and scholars. On the other hand, open discussions about death are avoided and ignored since they evoke unpleasant emotions in people and are even treated as awkward. Changes in attitudes and opening society to the problems of death and the conditions in which it takes place is significant for the way death is experienced by the dying themselves, their close family and friends and the medical staff providing care. The way we feel and think about death, what we believe in, and the values we assign to it greatly impact how society, institutions, and families say goodbye to their departed members.

COVID-19's lesson is not a clear-cut thanatological lesson, but it has undoubtedly contributed to the de-tabooization of dying and death by means of intensifying social emotions around these issues. It has also revealed great constructive and destructive layers in individuals and social groups. Such strong social experiences have made people aware of the need to search for ways of coping with death so that it would bring support and not destruction to one's environment, despite the unrest that COVID-19 has also caused. It could be said that this is the first in a series of lessons on how to live with death and maintain distance and creativity, being grounded in the present and rooted in relationships, peace, joy and care. This lesson has undoubtedly been different than other pandemic experiences due to its more global character. Thanks to the mass media, social media and other forms of bridging social distance, humanity has experienced and is still experiencing this pandemic situation in a new way. COVID-19 has shown the 
important aspects of social relations and that what death has taken from people - family, relationships, health, physical fitness, work - while the long-term effects of this virus remain unknown. While summarising these reflections on understanding COVID-19, I would like to put forward the following claim: COVID-19 is a shocking phenomenon on a global scale that has mainly contributed to intensifying people's fear of death. In certain situations, it has caused that people have cut themselves off from the awareness of their own death even more and have started to celebrate life. Others, however, have initiated thanatological reflection resulting in changes in their attitude towards death or encouragement to do so. It has also grounded thanatological thought in shaping knowledge about dying. Perhaps, if people (not only thanatologists) seriously worked on building awareness of their own passing, they would confront it and engage in open discourse, make use of their resources more creatively and reduce the fear that could be the source of increasing aggression and competition. Furthermore, they would ground themselves in the present to a greater extent, without expectations and memories that often anchor them and hamper their potential. For this to occur, thanatological education and research on the long-term effects that COVID-19 will have on family relationships, the social mourning process and taming death by means of the coronavirus are needed. This topic is certainly a fertile thanatological phenomenon worth further attention.

\section{Notes}

1 Reykjavik-based deCODE, a company that analyses the human genome, has tracked 40 coronavirus mutations. Research results have yet to be published, however this research company can be trusted as key genetic risk factors of various diseases from cardiovascular diseases to cancer have been discovered in their laboratories. DeCODE Genetics tested 9,768 samples taken from Icelanders for SARS-CoV-2, and then subjected the isolated virus to full genome sequencing that revealed certain findings regarding the evolution of pathogens and its transmission chain. The company's director, Kári Stefánsson, announced that 40 mutations had been detected in the inhabitants of the island. One individual was infected with two separate variations of the virus. The Icelandic Ministry of Health tested anyone who had shown signs of infection or were qualified as people at risk of contracting COVID-19. Furthermore, deCODE Genetics tested 5,571 people who did not have any symptoms and were not at risk, but volunteered themselves for testing. It turned out that among them, there were 48 asymptomatically infected individuals. https://www.bloomberg.com/news/articles/2020-04-22/iceland-is-the-perfect-country-for-studying-covid-19 (1.05.2021)

2 Here, reference should be made to two mathematical models created by two academic teams - a research team at Columbia University has constructed a mathematical model that gives a much more complete - and scary - picture of how much virus is circulating in our communities (https:/www.npr.org/sections/ health-shots/2021/02/06/964527835/why-the-pandemic-is-10-times-worse-thanyou-thin). Another mathematical model created by scientists at the University in Białystok based on the number of deaths should also be noted, compare (https:// covid-model.net/). 
3 I intentionally do not refer to specific scholars and specific points of view, because the objective of this chapter is not to provide such an overview. I believe that pointing out selected authors would set out a philosophical perspective in this text, which this would miss the main purpose of this chapter - analyzing the dying process and death in the social perspective. Professor Gogacz provides a solid philosophical overview of the concept of death, cf., http://katedra.uksw. edu.pl/gogacz/artykuly/028_filozof_ujecie_smierci_wydruk.pdf

4 Based on this observation, Freud came to the conclusion that

Our unconscious therefore does not believe in its own death; it acts as though it were immortal. What we call our unconscious, those deepest layers in our psyche which consist of impulses, recognizes no negative or any form of denial and resolves all contradictions, so that it does not acknowledge its own death, to which we can give only a negative content. The idea of death finds absolutely no acceptance in our impulses. (...) The fear of death, which controls us more frequently than we are aware, is comparatively secondary and is usually the outcome of the consciousness of guilt.

https://www.gutenberg.org/files/35875/35875-h/35875-h.htm

\section{References}

Aries, P., Człowiek i śmierć [Images of Man and Death], PIW, Warszawa, 1998.

Bauman, Z., Śmierć i nieśmiertelność, O wielości strategii życia [Mortality, Immortality, and Other Life Strategies], Wydawnictwo Naukowe PWN, Warszawa, 1998.

Berger, P., Święty baldachim. Elementy socjologiczneh teorii religii [The Sacred Canopy: Elements of a Sociological Theory of Religion], Zakład Wydawniczny Nomos, Kraków, 1997.

Buber, M., Ja i Ty [I and Thou], Instytut Wydawniczy PAX, Warszawa, 1992.

Cicirelli, V.G., Personal Meanings of Death in Relation to Fear of Death, Death Studies, 22 (8), 11/1998.

Feifel, H. \& Branscomb, A., Who's afraid of death. Journal of Abnormal Psychology, 81/1973.

Freud, S., Our Attitude Towards Death, [in:] idem, Reflections on War and Death, New York, 1918. https://www.bartleby.com/282/2.html

Gadamer, H.G., Prawda i metoda. Zarys hermeneutyki filozoficznej [Truth and Method], trans. B. Baran, Inter Esse, Kraków, 1993.

Gadamer, H.G., Doświadczenie śmierci [The Experience of Death], trans. A. Przyłębski, [in:] idem, O skrytości zdrowia [On the Secretiveness of Health], Poznań, pp. 79-90, 2011.

Gesser, G., Wong, P.T.P., Reker, G.T., Death Attitudes across the Life-Span: The Development and Validation of the Death Attitude Profile (DAP), OMEGA - Journal of Death and Dying, 18 (2) 03/1988.

Gorer, G., The Pornography of Death, [in:] G. Gorer (ed.), Death, Grief, and Mourning. Doubleday, New York, 192-199, 1955.

Heidegger, M., Bycie i czas [Being and Time], trans. B. Baran, Wydawnictwo Naukowe PWN, Warszawa, 1994.

Howarth, G., Death and Dying. A Sociological Introduction, Polity Press, Cambridge, 2008.

Jankélévitch, V., Tajemnica śmierci i zjawisko śmierci [The Mystery of Death and the Phenomenon of Death], [in:] Antropologia śmierci. Myśl francuska, selection 
and trans. S. Cichowicz, J. M. Godzimirski, Wydawnictwo Naukowe PWN, Warszawa, 1993.

Jankélévitch, V., To, co nieuchronne. Rozmowy o śmierci [The Inevitable. Conversations About Death], PIW, Warszawa, 2005.

Kaczmarek, A., Śmierć. Poszukiwanie znaczenia w kontekstach kulturowych, społecznych i politycznych [Death. The Search for Meaning in Cultural, Social and Political Contexts], [in:] Teka Komisji Politologii i Stosunków Międzynarodowych PAN, 4/2009.

Kastenbaum, R., Śmierć psychologiczna [Phychological Death], [in:] L. Pearson (ed.), Śmierć i umieranie. Postępowanie z człowiekiem umierającym [Death and Dying. Dealing with the Dying], PZWL, Warszawa, 1973.

Kielanowski, T., Przedmowa [Intorduction], [in:] L. Pearson (ed.), Śmierć i umieranie [Death and Dying], PZWL, Warszawa, 1975.

Kolbuszewski, J., Kryzys, pornografia i renesans śmierci [Crisis, Pornography and the Renaissance of Death], [in:] J. Kolbuszewskiego (ed.), Problemy współczesnej tanatologii [The Problems of Contemporary Thanatology], vol. I, WTN, Wrocław, 1997.

Kübler-Ross, E., Rozmowy o śmierci i umieraniu [Conversations about Death and Dying], PAX, Warszawa, 1979.

Kübler-Ross, E., Życiodajna śmierć [Life-giving Death], Księgarnia św. Wojciecha, Poznań, 2005.

Levinas, E., Całość i nieskończoność, Esej o zewnętrzności [Totality and Infinity. An Essay on Exteriority], PWN, Warszawa, 2012.

Makselon, J., Struktura wartości a postawa wobec śmierci [The Structure of Values and Attitudes Towards Death], Katolicki Uniwersytet Lubelski, Lublin, 1983.

Makselon, J., Lęk wobec śmierci. Wybrane teorie i badania psychologiczne [The Fear of Death. Selected Theories and Phychological Research], Polskie Towarzystwo Teologiczne, Kraków, 1998.

Mellor, P., Death in High Modernity: The Contemporary Presence and Absence of Death, [in:] D. Clark (ed.), The Sociology of Death, Oxford University Press, Oxford, 1993.

Neimeyer, R.A. (ed.), Death Anxiety Handbook: Research, Instrumentation, and Application. Taylor \& Francis, Washington, DC, 1994.

Ostrowska, A., Śmierć w doświadczeniu jednostki i społeczeństwa [Death in the Individual and Social Experience], Wydawnictwo IFiS PAN, Warszawa, 1997.

Szaniawski, T., Typy postaw wobec śmierci a osobowość [Types of Attitudes Towards Death and Personality], PAT, 1998.

Thomas L.V., Tworzenie tanatologii [Creating Thanatology], trans. M.L. Kalinowski [in:] Wymiary śmierci, Słowo/obraz terytoria [Dimensions of Death, Word/image territory], Gdańsk, 2002.

Tischner, J., Myślenie wedtug wartości [Thinking in Values], Wydawnictwo Znak, Kraków, 2005.

Tischner, J., Filozofia dramatu [The Philosophy of Drama], Wydawnictwo Znak, Kraków, 2006.

Tomer, A. \& Eliason, G., Toward a Comprehensive Model of Death. Death Studies, 20, 1996.

Vovelle, M., Historia ludzi w zwierciadle śmierci [The History of Humanity in the Light of Death], trans. M. Ochab, [in:] S. Rosiek (ed.), Wymiary śmierci [Dimensions of Death], Gdańsk, 2002. 
Vovelle, M., Śmierć w cywilizacji zachodu. Od roku 1300 po współczesność, Stowol obrazlterytoria [Death in the Western World. From 1300 to the Contemporary Era, Word/image/territory], Gdańsk, 2008.

Vuillemin, J., Śmierć w oczach zwierzęcia [Death in the Eyes of Animals], [in:] S. Cichowicz, J.M. Godzimirski (ed.), Antropologia śmierci. Myśl francuska [The Anthropology of Death. French Thought], PWN, Warszawa, 1993.

Walter, T., The Revival of Death, Routledge, London, 1994.

Wittgenstein, L., Tractatus logico-philosophicus, trans. and introduction by B. Wolniewicz, Wydawnictwo Naukowe PWN, Warszawa, 2000, p. 81, teza 6.431.

Yalom, I.D., Staring at the Sun: Overcoming the Terror of Death, Jossey-Bass, San Francisco, CA, 2008. Reviewed by Yvonne B. Bregman, M.A., M.S.W., Ridgefield, CT.

Ziemiński, I., Twoja śmierć. Próba eksplikacji doświadczenia śmierci [Your Death. An Attempt to Explain the Experience of Death], "Diametros" no. 11, 2007.

\section{Internet sources}

Gebert, K., Jednostka wobec śmierci [The Individual in the Face of Death], http:// www.jednota.pl/archiwum/o-smierci/303-jednostka-wobec-mierci

Gogacz,M.,http://katedra.uksw.edu.pl/gogacz/artykuly/028_filozof_ujecie_smierci_ wydruk.pdf

https://www.bloomberg.com/news/articles/2020-04-22/iceland-is-the-perfectcountry-for-studying-covid-19

https://covid-model.net/

https://www.bloomberg.com/graphics/2020-coronavirus-cases-world-map/

https://www.npr.org/sections/health-shots/2021/02/06/964527835/why-thepandemic-is-10-times-worse-than-you-thin

Jastrzębski, J., Psychologiczny wymiar lęku przed śmiercią [The Psychological Dimension of the Fear of Death], http://www.psychologia.net.pl/artykul.php? level $=209$ 